\title{
Prevalence of some virulence genes and antibiotic susceptibility pattern of Pseudomonas aeruginosa isolated from different clinical specimens
}

\author{
Yamuna Chand \\ National College \\ Santosh Khanal \\ National College \\ Om Prakash Panta \\ National College \\ Dipendra Shrestha \\ National College \\ Dhruba Kumar Khadka
}

Bir Hospital

Pramod Poudel ( $\sim$ poudel.pm@gmail.com )

University Grants Commission of Nepal

\section{Research}

Keywords: Pseudomonas aeruginosa, oprL, toxA, MDR.

Posted Date: April 28th, 2020

DOl: https://doi.org/10.21203/rs.3.rs-24044/v1

License: (c) (1) This work is licensed under a Creative Commons Attribution 4.0 International License.

Read Full License 


\section{Abstract}

Background: Pseudomonas aeruginosa is an opportunistic human pathogen and are reported to cause acute and chronic infectious diseases. Due to its high ability to acquire resistance to many antibiotics, it has become a global public health threat. It consists of some virulence genes that may lead to its pathogenicity. The main objective of this cross-sectional study was to detect the virulence genes and antibiotic susceptibility pattern of $P$. aeruginosa isolated from clinical specimens collected from governmental hospital of Nepal.

Methods: A total of 7898 clinical specimens were analyzed for the period of six months from November 2018 to April 2019. The specimens were cultured on Nutrient agar, Blood agar, MacConkey agar, Chocolate agar, Cysteine-Lactose, Electrolyte Deficient agar plates and were incubated at $37^{\circ} \mathrm{C}$ for 24 hours. All the isolates were identified by standard biochemical tests and further confirmed by growth on Cetrimide agar plate. The antibiotic susceptibility testing was performed by modified Kirby-Bauer disc diffusion method following CLSI guideline. Multiplex-PCR was done to detect the virulence genes oprL and toxA. Statistical analysis was carried out using IBM SPSS Statistic ver. 25 and the p-value was calculated at significance level $(0.05 \%)$ by using Chi square.

Results: Out of these specimens investigated, 87 isolates were tentatively identified to be $P$. aeruginosa in which $20(22.98 \%)$ were found to be multidrug resistant. Comparatively, most of the $P$. aeruginosa were isolated from outpatients $63(72.41 \%)$ than inpatients 24 (27.58 \%), from male 56 (64.36\%) than female $31(35.63 \%)$ and in age group $60-79$ years $(41.37 \%)$. AST result showed the highest resistance of $100 \%$ with cefixime whereas susceptibilities of $83.9 \%$ and $81.6 \%$ with polymixin $B$ and tobramycin were noticed respectively. The PCR results showed that all $P$. aeruginosa isolates carried oprL 87 (100\%) and 83 (95.4 $\%)$ isolates showed toxA genes.

Conclusion: The studies revealed that almost all $P$. aeruginosa harbors both oprL and toxA genes.

\section{Background}

Pseudomonas aeruginosa is known as one of the most-widely spread opportunistic human pathogen causing 18 to $63 \%$ infection worldwide $(1,2)$. It has the ability to grow at temperature $42{ }^{\circ} \mathrm{C}$, this unique character helps to differentiate from many other Pseudomonas species (3). Most strains produce water soluble pigments, such as pyocyanin, pyoverdin, pyorubin and pyomelanin (4-5). The ability of $P$. aeruginosa to grow in minimum nutritional requirements and to withstand various physical condition has assigned these organism to persist in both hospital and community settings (6-7).

$P$. aeruginosa having great diversity and capable of causing life threatening contagion infections in a multifariousness of patients population (8). There are several extracellular and cell associated virulence factors that may lead to its pathogenicity. The colonization of these factors can cause blood stream invasive, extensive tissue damage and dissemination. Some genes, normally encode and participate in the virulence factors are, toxA, exoS, exoY, exoU, oprL, oprl, lasA, lasB, oprD, plcH, plcN and nan1 etc. (9). 
Virulence genes such as oprL, oprl and oprD are the major outer membrane lipoproteins, specific to $P$. aeruginosa only and true factors for identification of $P$. aeruginosa infections (10). Similarly, tox $A$ gene is one of the virulence genes that encode exotoxin A produced by $P$. aeruginosa and inhibits protein biosynthesis by stop elongation of polypeptide chains (11-13).

Among all the investigating tools, DNA typing techniques have been often used to investigate the divergence of $P$. aeruginosa (14). Proteins can also be identify by matrix-assisted leser desorption/ionization time-of-flight mass spectrometry (MALDI-TOF MS) (15).

This cross-sectional study is designed to assist the current resistant against different classes of antibiotics and to characterize $P$. aeruginosa by identifying virulence genes oprL and tox $A$ using polymerase chain reaction (PCR).

In Nepal, the increasing trend of antimicrobial resistant property of $P$. aeruginosa is becoming an alarming health issues. There are no exact observable scheme for marking resistant pattern and its use in Nepal. Additionally, few researches and some available secondary data are not sufficient to study current scenario and it is really hard to describe the true positive trends of antibiotic resistant of $P$. aeruginosa in Nepal. Therefore this cross-sectional study is designed to assist the current resistant pattern of $P$. aeruginosa against different classes of antibiotics and to identify the involvement of several virulence genes in resistant mechanisms by using Polymerase Chain Reaction (PCR) which ultimately helps to select appropriate antibiotics useful for the treatment of infectious disease caused by $P$. aeruginosa.

\section{Methods}

This cross-sectional study was conducted between November 2018 to April 2019 at Bir Hospital (a tertiary care hospital), National Academy of Medical Sciences (NAMS), Kathmandu, Nepal and Department of Microbiology at National College (NIST), Kathmandu Nepal. In this study, clinical and socio-demographic study of patients was also performed. In total, 7898 different clinical specimens were collected and cultured semi-quantitatively on Nutrient agar, blood agar, MacConkey agar. It was confirmed by using cetrimide agar medium and standard biochemical tests. The antibiotic susceptibility testing was performed on Muller Hinton agar by modified Kirby-Bauer disc diffusion method. Strains were considered as multi drug resistant (MDR) if they were resistant to at least 4 of following antimicrobial agents belonging to different classes of antibiotics: Imipenem, Ceftazidime, Tobramycin or Gentamicin and Ciprofloxacin (16). Diameter of the zone of inhibition for each antibiotic was measured and interpreted as recommended by Clinical and Laboratory Standard Institute (CLSI) guideline (2018) (17-18).

\section{DNA Extraction}

For the identification of virulence genes (oprL and toxA), chromosomal DNA was extracted from each $P$. aeruginosa isolate by phenol-chloroform assay (19).

\section{Detection of Virulence Genes by using PCR}


The PCR amplification was carried out by using temperature gradient thermal cycler (PCR tube 96 wells, Takara/Japan) with specific forward and reverse primer for the detection of oprL, and toxA genes respectively. The primer was then diluted to working concentration of $10 \mathrm{Pm}$ by using nuclease free water (Table 1).

The PCR was carried out in total $20 \mu$ volume of reaction mixtures containing $2 \mu \mathrm{l}$ of template DNA, $1 \mu \mathrm{l}$ of each primer, $4 \mu$ of master mixtures, $12 \mu$ of nuclease free water and Taq-polymease enzyme with 35 cycles. The annealing temperature was $61.8^{\circ} \mathrm{C}$ for oprL, and $58.2{ }^{\circ} \mathrm{C}$ for toxA. The PCR condition is depicted in Table 1. The PCR products were separated by gel electrophoresis on $1 \%$ agarose gel containing $5 \mu$ of ethidium bromide. The band of size about $500 \mathrm{bp}$ and $352 \mathrm{bp}$ of oprL and toxA were produced respectively along with $100 \mathrm{bp}$ DNA marker and positive control (20).

Table 1

Nucleotide sequence of primers and condition used to amplify species specific virulence genes in $P$. aeruginosa by PCR

\begin{tabular}{|c|c|c|c|c|c|}
\hline $\begin{array}{l}\text { Virulence } \\
\text { factors }\end{array}$ & $\begin{array}{l}\text { Target } \\
\text { genes }\end{array}$ & $\begin{array}{l}\text { Primer } \\
\text { name }\end{array}$ & Sequence (5区 to $3 \rrbracket)$ & $\begin{array}{l}\text { Annealing } \\
\text { temperature, }{ }^{\circ} \mathrm{C}\end{array}$ & $\begin{array}{l}\text { Amplicon } \\
\text { size (bp) }\end{array}$ \\
\hline \multirow[t]{2}{*}{ Exotoxin A } & toxA & toxA-f & $\begin{array}{l}\text { GGT AAC CAG CTC AGC } \\
\text { CAC AT }\end{array}$ & \multirow[t]{2}{*}{58.2} & \multirow[t]{2}{*}{352} \\
\hline & & toxA-r & $\begin{array}{l}\text { TAG TGT CCA GGT CAT } \\
\text { GCT TC }\end{array}$ & & \\
\hline \multirow[t]{2}{*}{$\begin{array}{l}\text { Sialidase } \\
\text { enzyme }\end{array}$} & oprL & oprL-f & $\begin{array}{l}\text { ATG GGA ATG CTG AAA } \\
\text { TTC GGC }\end{array}$ & \multirow[t]{2}{*}{$61.8^{\circ} \mathrm{C}$} & \multirow[t]{2}{*}{500} \\
\hline & & oprL-r & $\begin{array}{l}\text { CTT CTT CAG CTC GAC } \\
\text { GCG ACG }\end{array}$ & & \\
\hline
\end{tabular}

\section{Statistical analysis}

Data was analyzed using IBM SPSS ver. 25. Pearson's correlation test were used to detect significance of the result. The $p$-value was calculate at significance level (0.05\%) (20).

\section{Results}

Among 7898 clinical specimens, a total of $2026(26 \%)$ showed significant growth (i.e., $10^{5} \mathrm{cfu} / \mathrm{ml}$ ) out of which 87 (4.29\%) isolates were $P$. aeruginosa.

\section{Clinical and socio-demographic study}

The highest number of $P$. aeruginosa was isolated from male patients $56(64.36 \%)$ and community acquired infections was found to be greater which accounts 63 (72.41\%). In addition, the substantial number $36(41.37 \%)$ of $P$. aeruginosa were found in age group 60-75 (Table 2). 
Table 2

Clinical and socio-demographic study

\begin{tabular}{|lll|}
\hline S. No. & Status of patients & Number (\%) \\
\hline 1 & Male & $56(64.36)$ \\
\hline 2 & Female & $31(35.63)$ \\
\hline S.No. & Gender & Number (\%) \\
\hline 1 & In-patients & $24(27.58)$ \\
\hline 2 & Out-patients & $63(72.41)$ \\
\hline S.No. & Age distribution (years) & Number (\%) \\
\hline 1 & $1-19$ & $6(6.89)$ \\
\hline 2 & $20-39$ & $16(18.39)$ \\
\hline 3 & $40-59$ & $24(27.58)$ \\
\hline 4 & $60-79$ & $36(41.37)$ \\
\hline 5 & $>79$ & $5(5.47)$ \\
\hline
\end{tabular}

\section{Antibiotic Susceptibility Pattern of $P$. aeruginosa}

Table 3 shows the antibiotic susceptibility pattern of $P$. aeruginosa isolates. Polymyxin, Tobramycin, Gentamicin, Imipenem and Ceftazidime were the most effective antibiotics in-vitro with sensitivitities of 73 (83\%), 71 (81.60\%), 69 (79.31\%), 63 (72.41\%), and 61 (70.11\%) respectively. On the other hand, all the $P$. aeruginosa isolates were resistant (100\%) to cefexime. 
Table 3

Antibiotic Susceptibility Pattern of $P$. aeruginosa

\begin{tabular}{|llll|}
\hline Antibiotics used & $\begin{array}{l}\text { Sensitive } \\
\mathbf{N}(\%)\end{array}$ & $\begin{array}{l}\text { Intermediate } \\
\mathbf{N}(\%)\end{array}$ & $\begin{array}{l}\text { Resistant } \\
\mathbf{N}(\%)\end{array}$ \\
\hline Aztreonam & $58(66.66)$ & $21(24.13)$ & $8(9.19)$ \\
\hline Ceftazidime & $61(70.11)$ & $0(0)$ & $26(29.88)$ \\
\hline Carbenicillin & $30(34.48)$ & $16(18.39)$ & $41(47.12)$ \\
\hline Cirpofloxacin & $59(67.81)$ & $1(1.14)$ & $27(31.03)$ \\
\hline Gentamicin & $69(79.31)$ & $0(0)$ & $18(20.68)$ \\
\hline Imipenem & $63(72.41)$ & $0(0)$ & $24(27.58)$ \\
\hline Norfloxacin & $56(64.36)$ & $0(0)$ & $31(35.36)$ \\
\hline Nitrofurantoin & $0(0)$ & $0(0)$ & $40(100)$ \\
\hline Piperacillin & $54(62.06)$ & $10(11.49)$ & $23(26.43)$ \\
\hline Piperacillin-tazobactam & $37(78.72)$ & $1(2.12)$ & $9(19.14)$ \\
\hline Polymixin & $73(83.90)$ & $14(16.09)$ & $0(0)$ \\
\hline Cefexime & $0(0)$ & $0(0)$ & $87(100)$ \\
\hline Tobramyycin & $71(81.60)$ & $0(0)$ & $16(18.39)$ \\
\hline $\begin{array}{l}\text { As shown in Table 4, out of } 87 \text { P. aeruginosa isolates, the maximum number of MDR P. aeruginosa } \\
\text { (MDRPA) was isolated from pus (30.76\%) which followed by urine (30\%) and sputum (16.66\%). }\end{array}$ \\
\hline
\end{tabular}

Table 4

Distribution of MDR $P$. aeruginosa isolates among different clinical specimens

\begin{tabular}{|lll|}
\hline Specimens & Number of $\boldsymbol{P}$. aeruginosa isolates $\mathbf{N}(\%)$ & Number of MDRPA isolates $\mathbf{N}(\%)$ \\
\hline Urine & $40(3.09)$ & $12(30)$ \\
\hline Sputum & $24(12.06)$ & $4(16.66)$ \\
\hline Pus & $13(4.48)$ & $4(30.76)$ \\
\hline Blood & $2(1.81)$ & $0(0)$ \\
\hline Body fluid & $8(6.01)$ & $0(0)$ \\
\hline Total & $\mathbf{8 7}$ & $\mathbf{2 0}$ \\
\hline
\end{tabular}

Out of 87 total isolates, $83(95.4 \%) P$. aeruginosa isolates showed the presence of tox $A$ virulence genes whereas oprL gene was detected in all of the collected $P$. aeruginosa isolates 87 (100\%) (Table 5). 
Table 5

Prevalence of virulence genes (oprL and toxA) in $P$. aeruginosa

\begin{tabular}{|lllllll|}
\hline $\begin{array}{l}\text { Virulence } \\
\text { genes }\end{array}$ & \multicolumn{3}{l}{ Specimen type } & & & \multicolumn{1}{l|}{$\begin{array}{c}\text { Total } \\
\text { N (\%) }\end{array}$} \\
\cline { 2 - 7 } & Urine & Sputum & Pus & Blood & Body fluid & \\
& $\mathrm{n}(\%)$ & $\mathrm{n}(\%)$ & $\mathrm{n}(\%)$ & $\mathrm{n}(\%)$ & $\mathrm{n}(\%)$ & \\
\hline oprL & $40(100)$ & $24(100)$ & $13(100)$ & $2(100)$ & $8(100)$ & $87(100)$ \\
\hline toxA & $40(100)$ & $21(87.5)$ & $12(92.30)$ & $8(100)$ & $2(100)$ & $83(95.40)$ \\
\hline
\end{tabular}

\section{Discussion}

$P$. aeruginosa is associated as a versatile opportunistic human pathogen and its ultimate infection is reported to complete by attachment, colonization, local invasion and dissemination as a systemic disease $(21-22)$.

In this study, the prevalence of $P$. aeruginosa isolates was $4.29 \%$, in which the distribution in male patients $56(64.36 \%)$ was higher than in female patients 31 (35.63\%). The possible reasons might be types of studied populations, different geographical locations, type of hospitals. In addition, other reasons may be the male have a routine outdoor work and they are frequently in the risk of infection from the infected environments (16). The prevalence rate of infections was higher in outpatients $63(72.41 \%)$ compared to the hospital admitted patients $24(27.58 \%)$ which may be due to frequent exposure to infected environment. In addition, the occurrence of $P$. aeruginosa isolates to be greater in the age group 60-79 (41.37\%), infection caused by $P$. aeruginosa is more common in patients of old age group. This could be described as because of decrease immune system, prolonged duration of hospitalization (2325).

In our study, the difference between gender of patients and $P$. aeruginosa isolation from different clinical specimens was found to be statistically significant $(p=0.016)$. Likewise, the difference between type of patients and $P$. aeruginosa isolated from different clinical specimens was found to be statistically significant $(p=0.009)$. There was no statistical significance between the different age groups and occurrence of $P$. aeruginosa in male and female patients $(p=0.071)$ at $5 \%$ level of significance.

In this study, the most effective drug for $P$. aeruginosa isolates was found to be polymyxin B 73 (83.90\%), also called last resort antibiotic for Pseudomonadecae family in the hospitals and less effective antibiotic was cefixime $87(100 \%)$. Out of $87 P$. aeruginosa isolates, $20(22.98 \%)$ were identified to be MDRPA. The development of antibiotic resistant towards $P$. aeruginosa might be due random use of antibiotics, production of different types of enzyme like carbapenamase, AmpC-lactamases, quorum sensing modification of different target side etc $(26,13)$. Furthermore, one of the major cause of the 
emergence of $P$. aeruginosa is prescribing the antibiotics without performing susceptibility test due to lack of laboratory facilities in most of the healthcare centers in Nepal (16, 24, 27-28).

The PCR results showed that $87(100 \%)$ of 87 P. aerugiosa isolates were positive for oprL genes. Similarly in this study $83(95.40 \%)$ of $87 P$. aeruginosa were positive for toxA gene. Almost comparable study was carried out by Ibraheem at 2018 which showed $100 \%$ of toxA and $98.8 \%$ oprL genes. According to the Khattab et al in (2015), $100 \%$ of oprL gene, and $63.33 \%$ toxA gene were reported among the $P$. aeruginosa. The divergences in the distribution of virulence factor genes in the different populations might be due to the probability that some $P$. aeruginosa strains are better adopted to the particular conditions found in infectious sites that may returned to the diverse geographical and environmental sources. The prevalence of $P$. aeruginosa and its virulence genes depends on various causes consisting nature of places, degree of contamination and type, immune status of individual patients and virulence of strains (29).

Exotoxins $A$ are either actively secreted through the type 1 secretion system (T1SS), the type 2 secretion system (T2SS), and the type 3 secretion system (T3SS) or passively secreted via the cell (27). The exotoxin $\mathrm{A}$ is encoded by gene called exoA which is involved in the tissue necrosis and resistant to antibiotics (28). The $\mathrm{L}$, and I are two outer membrane lipoproteins of $P$. aeuginosa are found only in this organism, so that they could be a suitable factors for rapid identification of $P$. aeruginosa in clinical specimens. This bacterium is also answerable for inherent resistance to antiseptics and antibiotics (29).

In this study, detection of $P$. aeruginosa by multiplex PCR for amplification of oprL gene, present study showed that of 87 tested $P$. aruginosa isolates $87(100 \%)$ contained the oprL gene (sensitivity $=100 \%$ ), where as other species of bacteria did not produce any positive result (specificity $=100 \%$ ). While amplification of the tox $A$ gene showed that of 87 tested $P$. aeruginosa isolates $83(95.40 \%)$ contained the tox $A$ gene (sensitivity $=95 \%$ ), where as other species of bacteria did not yield any positive result (specificity $=100 \%$ ). This study revealed that the multiplex PCR may be one of the rapid diagnostic tool for the identification of $P$. aeruginosa infections.

\section{Conclusion}

In this research, polymyxin and amynogycocides were found to be functional antibiotics for treatment and the studies revealed that almost all $P$. aeruginosa harbors both oprL and toxA genes. Additional studies might be required to confirm the pathogenicity and increasing trends of antibiotic resistance pattern of $P$. aeruginosa.

\section{Limitations of study}

Study has limitations as minimum inhibitory concentration and $16 \mathrm{~s}$ rRNA sequencing for $P$. aeruginosa were not performed because of cost and unavailability of laboratories respectively. Despite of all, only tox $A$ and $\operatorname{opr} L$ genes were taken as an identification keys because of expensiveness. 


\section{Abbreviations}

CLSI: Clinical and laboratory Standards Institute, MDRPA: Multidrug resistant Pseudomonas aeruginosa

\section{Declarations}

\section{Acknowledgements}

The authors are greatly thankful to the subjects involving in this study. The authors also grateful to the staff of Microbiology laboratory of National Academy of Medical Sciences (NAMS), Bir Hospital for their kind support in the collection of data and performing the essential laboratory tests during the study. And equally thankful to the staff of Department of Microbiology and Department of Biotechnology at National College as equipment facilities installation for molecular level examination.

\section{Authors' contributions}

YC designed the research proposal, conducted laboratory work, data analysis and drafted the manuscript under the guidance of PP and DKK. OPP, SK and DS were responsible for data analysis and reviewing the manuscript. All authors read and approved the final manuscript.

\section{Funding}

There was no funding organization for this work.

\section{Availability of data and materials}

Data sharing is not applicable to this study as the datasets created needed to be confidential

\section{Ethical approval and consent to participate}

The ethical clearance and consent to participate was approved by institutional review board (IRB), National Academy of Medical Sciences (NAMS), Bir Hospital, Kathmandu, Nepal.

\section{Consent for application}

Not applicable.

\section{Competing interest}

The authors declare that they have no competing interests.

\section{References}

1. Kang Cl, Kim SH, Kim HB, Park SW, Choe YJ, Oh MD and Choe KW (2003). Pseudomonas aeruginosa bacteremia: risk factors for mortality and influence of delayed receipt of effective antimicrobial 
therapy on clinical outcome. Clin Infect Dis 37(6): 745-751.

2. Odumosu, BT., Adeniyi BA and Chandra R (2013). Analysis of integrons and associated gene cassettes in clinical isolates of multidrug resistant Pseudomonas aeruginosa from Southwest Nigeria. Ann Clin Microbiol Antimicrob 12:

3. Todar K (2006). Todar's online textbook of bacteriology 4: 214.

4. Wu W, Jin Y, Bai F and Jin S (2015). Pseudomonas aeruginosa. Mol Medi Microbiol 753-767.

5. McKnight SL, Iglewski BH and Pesci EC (2000). The Pseudomonas quinolone signal regulates rhl quorum sensing in Pseudomonas aeruginosa. J Bacteriol182(10):2702-2708.

6. Moradali MF, Ghods S and Rehm BH (2017). Pseudomonas aeruginosa lifestyle: a paradigm for adaptation, survival, and persistence. Front Cel Infect Microbiol 7: 39.

7. Wisplinghoff H, Seifert $\mathrm{H}$ and Steven M (2019). Pseudomonas aeruginosa: A guide to infection control in the hospital 323-326.

8. Zeb A, Ullah I, Rehman HU and Rehman MU (2017). Antibiotic susceptibility patterns of Pseudomonas aeruginosa in tertiary care hospital. J Entomol Zool Stud 20: 50.

9. Haghi F, Zeighami H, Monazami A, Toutouchi F, Nazaralian S and Naderi G (2018). Diversity of virulence genes in multidrug resistant Pseudomonas aeruginosa isolated from burn wound infections. Microb Pathog 115: 251-256.

10. Nikbin VS, Aslani MM, Sharafi Z, Hashemipour M, Shahcheraghi F and Ebrahimipour GH (2012). Molecular identification and detection of virulence genes among Pseudomonas aeruginosa isolated from different infectious origins. Iranian J Microbiol 4(3): 118.

11. De Vos Daniel, Lim A, Pirnay JP, Struelens M, Vandenvelde C, Duinslaeger L and Cornelis P (1997). Direct detection and identification of Pseudomonas aeruginosa in clinical samples such as skin biopsy specimens and expectorations by multiplex PCR based on two outer membrane lipoprotein genes, oprl and oprL. J Clin Microbiol 35(6): 1295-1299.

12. Fazeli N and Momtaz H (2014). Virulence gene profiles of multidrug-resistant Pseudomonas aeruginosa isolated from Iranian hospital infections. Iran Red Crescent Med J 16(10): 15722.

13. Nikbin VS, Aslani MM, Sharafi Z, Hashemipour M, Shahcheraghi F and Ebrahimipour GH (2012). Molecular identification and detection of virulence genes among Pseudomonas aeruginosa isolated from different infectious origins. Iranian J Microbiol 4(3): 118.

14. Wolska K, Kot B and Jakubczak A (2012). Phenotypic and genotypic diversity of Pseudomonas aeruginosa strains isolated from hospitals in Siedlce (Poland). Braziln J Microbiol 43(1): 274-282.

15. Hare NJ, Solis N, Harmer C, Marzook NB, Rose B, Harbour C and Cordwell SJ (2012). Proteomic profiling of Pseudomonas aeruginosa AES-1R, PA01 and PA14 reveals potential virulence determinants associated with a transmissible cystic fibrosis-associated strain. BMC Microbiol12(1): 16.

16. Manandhar S, Adhikari S and Rajbhandari S (2017). Phenotypic Assays for Detection of AmpC and MBL Producers among the Clinical Isolates of Multi Drug Resistant Pseudomonas 
aeruginosa. Tribhuvan University J Microbiol4: 23-31.

17. Humphries RM, Ambler J, Mitchell SL, Castanheira M, Dingle T, Hindler JA and Sei K (2018). CLSI methods development and standardization working group best practices for evaluation of antimicrobial susceptibility tests. J Clin Microbiol 56(4): 1934-2017.

18. Patel JB, Cockerill FR and Bradford PA (2015). Performance standards for antimicrobial susceptibility testing: twenty-fifth informational supplement 35(3): 1-236.

19. Sambrook J, Russell DW. Molecular cloning: a laboratory manual. Cold Spring Harbor: Cold Spring Harbor Laboratory Press; 2001. p. 19-94.

20. Khattab MA, Nour MS and ElSheshtawy NM (2015). Genetic identification of Pseudomonas aeruginosa virulence genes among different isolates. J Microb Biochem Technol 7(5): 274-277.

21. Yadav VC, Kiran VR, Jaiswal MK and Singh K (2017). A study of antibiotic sensitivity pattern of Pseudomonas aeruginosa isolated from a tertiary care hospital in South Chhattisgarh. Int J Med Sci Public Health 6: 600-605.

22. Liew SM, Rajasekaram G, Puthucheary SDA, Chua KH (2019). Antimicrobial susceptibility and virulence genes of clinical and environmental isolates of Pseudomonas aeruginosa. Peer J 7:e6217.

23. Owlia P, Nosrati R, Alaghehbandan R and Lari AR (2014). Antimicrobial susceptibility differences among mucoid and non-mucoid Pseudomonas aeruginosa GMS Hyg Infect Cont 9(2): 2196-5226.

24. Shrestha S, Amatya R and Adhikari RP (2015). Prevalence and antibiogram of Pseudomonas aeruginosa isolated from clinical specimens in a Teaching Hospital, Kathmandu. Nepal Med Coll J 17(3-4): 132-135.

25. Srivinas B, Lalitha Devi D, Narasinga Rao B (2012). A prospective study of Pseudomonas aeruginosa and its antibiogram in a Teaching Hospital of Rular setup. J Pharma Biomed Sci 22(18): 1-5.

26. Javiya VA, Ghatak SB, Patel KR and Patel JA (2008). Antibiotic susceptibility patterns of Pseudomonas aeruginosa at a tertiary care hospital in Gujrat, India. Indian J Pharmacol 40(5): 230.

27. Anil C and Shahid RM (2013). Antimicrobial susceptibility patterns of Pseudomonas aeruginosa clinical isolates at a tertiary care hospital in Kathmandu, Nepal. Asian J Pharm Clin Res 6(3): 235308.

28. Basnyat B, Pokharel P, Dixit S and Giri S (2015). Antibiotic use, its resistance in Nepal and recommendations for action: a situation analysis. J Nepal Health Res Counc 13(30): 102-111.

29. Aljebory IS (2018). PCR Detection of Some Virulence Genes of Pseudomonas aeruginosa in Kirkuk city, Iraq. J Pharm Sci Resr 10(5): 1068-1071.

\section{Figures}




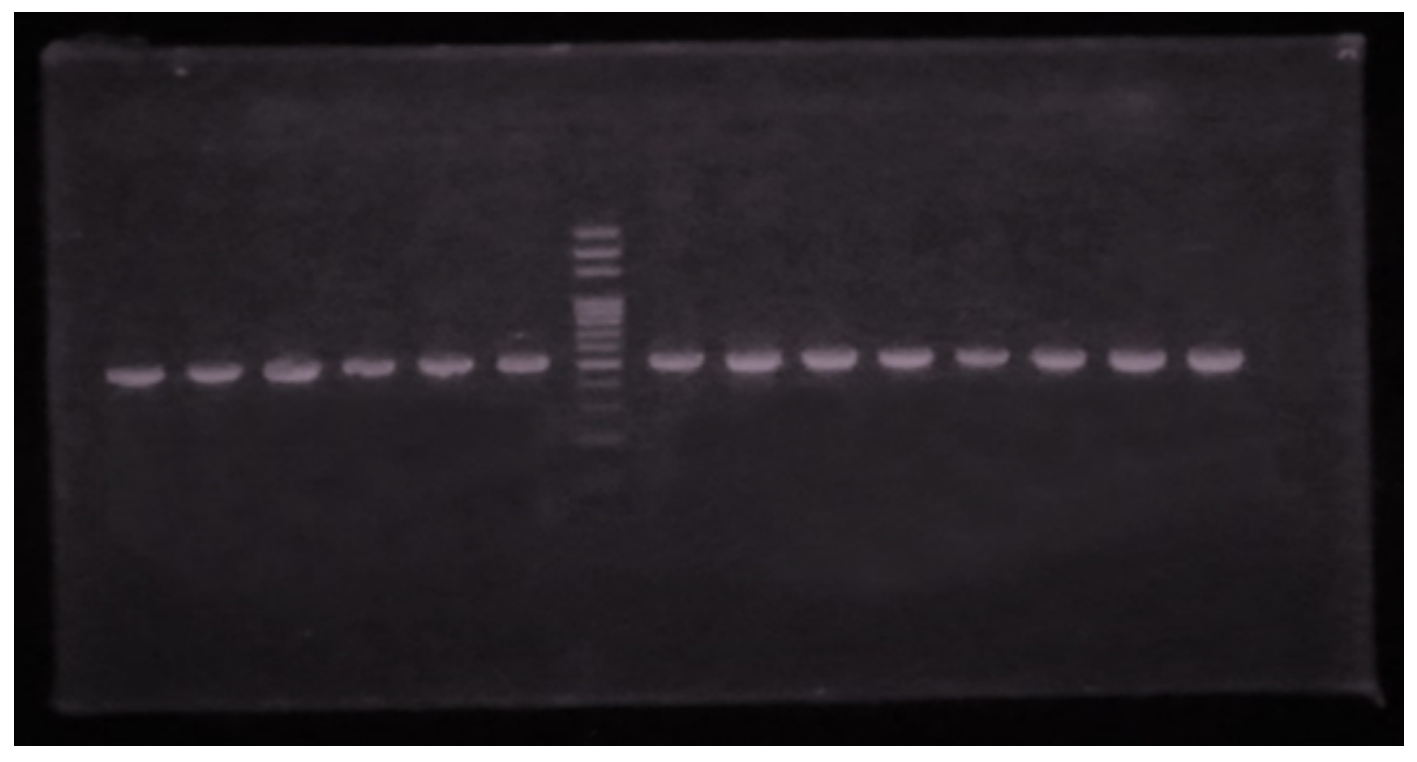

\section{Figure 1}

Agarose gel (1\%) electrophoresis of PCR assay of oprL gene (500 bp). From left to right bands U8, U14, $\mathrm{U} 5, \mathrm{U} 15, \mathrm{U} 7, \mathrm{U6}, \mathrm{B} 1, \mathrm{BF} 1, \mathrm{BF} 2, \mathrm{BF} 3, \mathrm{~S} 6, \mathrm{~S} 7$ and P8 indicates P. aeruginosa isolates with 100 bp marker, U12 represents positive control

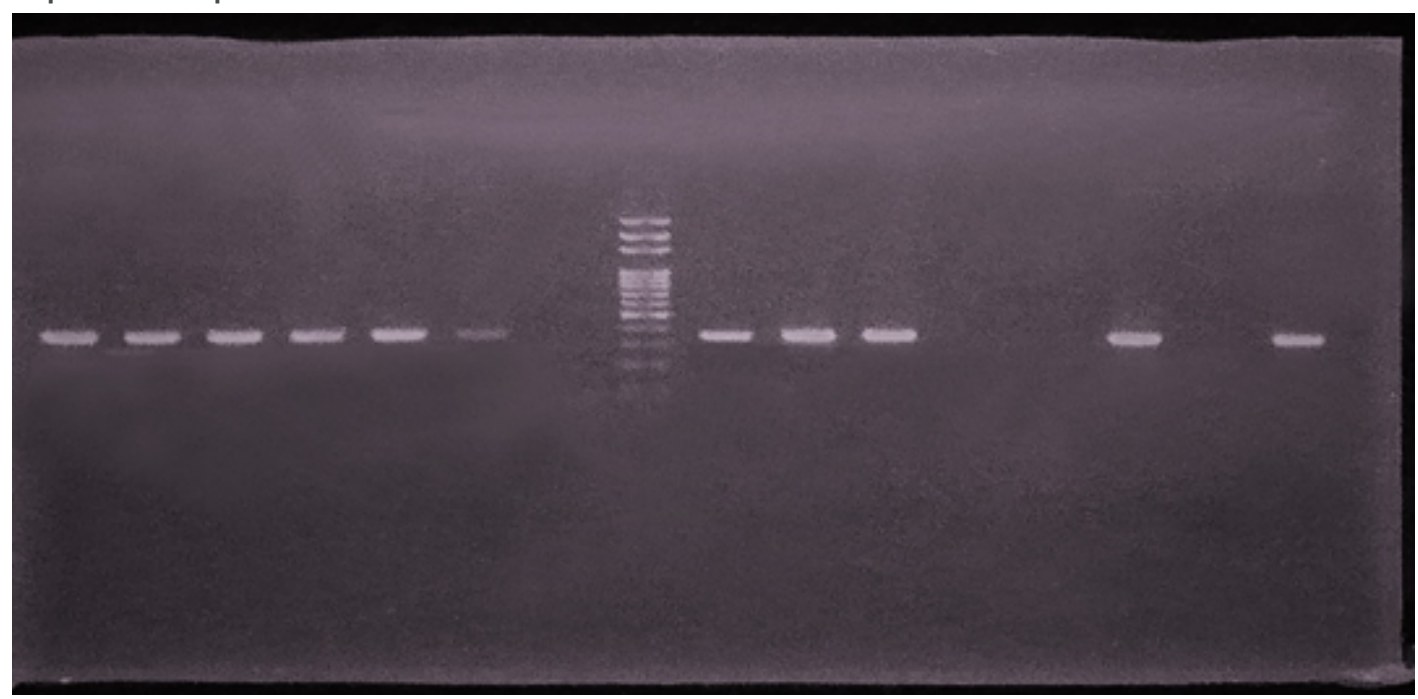

\section{Figure 2}

Agarose gel (1\%) electrophoresis of PCR assay of toxA gene (352 bp). From left to right bands U7, U8, $\mathrm{U} 18, \mathrm{U} 19, \mathrm{~B} 1, \mathrm{BF} 1, \mathrm{P} 6, \mathrm{P} 10, \mathrm{~S} 12$ and S24 indicates P. aerogenosa isolates, bands P4, S4, S7 and S17 indicates negative isolates with $100 \mathrm{bp}$ marker and band P5 represents positive control. 